\title{
MENTALIDAD Y ESTRUCTURAS MÁGICO-ERÓTICAS TRADICIONALES
}

\author{
Nicoleta Coatu \\ Instituto de Etnografía y Folclor «C. Brăiloiu» de la Academia \\ Rumana
}

\section{LAS PRÁCTICAS MÁGICO-ERÓTICAS: CAUSAS Y RASGOS CONSTITUTIVOS}

Si partimos de la premisa de que «sobre la base de una actitud completamente pasiva no se puede desarrollar ninguna energía creadora», podemos afirmar junto con E. Cassirer que, «desde este punto de vista, incluso la magia debe ser considerada un paso importante en el desarrollo de la conciencia humana. Creer en la magia es una de las más tempranas e importantes expresiones del despertar de la confianza en sí del ser humano. En este caso, ya no se siente sujeto a la buena voluntad de las fuerzas naturales o sobrenaturales» (Cassier, 1994: 130), sino las utiliza en sus proyectos cultural-mágicos. La colaboración con lo físico y lo metafísico, en la ordenación de la armonía existencial, le hace desempeñar un papel propio, como actor del espectáculo de la 
naturaleza, consciente de sus propias fuerzas, del poder de su propia voluntad y energía. Porque, una vez más señala y, con razón, E. Cassier: «lo que gana el ser humano a través de la magia es la concentración suprema de todos sus esfuerzos que, en circunstancias habituales, están dispersos o se muestran incoherentes» (Cassier, 1994: 131). Si los efectos responden a las expectativas —e incluso si los deseos del hombre no se realizan siempre y por completo, conforme a la expectación- la magia le enseña tener confianza en sus propias fuerzas, considerarse capaz, no sólo de sustraerse a las fuerzas de la naturaleza, sino de adaptarlas y de controlarlas gracias a la energía espiritual» (Cassier, 1994: 131). Entre interrogaciones que perturban su tranquilidad anímica y soluciones que debe encontrar para ponerse en acción, el ser humano ha buscado siempre el equilibrio, mantener la línea del destino, realizar el juego entre lo real y lo posible. Para ello, y porque aspira al orden social y universal, produce voluntariamente actos mágicos, creyendo que le será posible cambiar de imagen, embellecer su ser, alcanzar la plenitud erótica, con una finalidad marital.

1.1. La participación de los medios tradicional-folclóricos rumanos en el orden cósmico impone una jerarquía correctamente establecida de las cosas. La estructura y la dinámica de todo lo existente se ven condicionadas y orientadas por esta concepción integradora del mundo, por la comprensión de la interdependencia de los fenómenos. En la mentalidad sintética del hombre total, la organización social se suma a la armonía universal, combinando orgánicamente las determinaciones concretas-materiales con las espirituales, por medio de una permanente apertura hacia lo sagrado.

La intervención a través del acto mágico-erótico-pre-marital es motivada por la necesidad de equilibrio, de integrarse en el mundo, como estructura constituyente de lo existencial de tipo Dasein, en la plenitud sugerida por Heidegger en Das-in-der-Sein, en una relación de existencia, y no una simple relación de inherencia, de exterioridad. Situarse en el orden de lo social y de lo universal cósmico supone vocación personal, el deber de ser, perteneciente al registro del yo, en conformidad con la comunidad ontológica, implicando comunión hacia la existencia. Por pertenecer al ámbito comunitario, el individuo es lo que es y quiere ser en relación con las normas establecidas en la comunidad y con el principio de orden socio-humano y universal. El deber interior ontológico del ser de llegar a la plenitud de la existencia, por medio de la integración en la realidad microcósmica y macrocósmica, solicita la adecuación al modelo social que establece el itinerario de los individuos gober- 
nándolos al mismo tiempo. La dinámica existencial humana está marcada permanentemente por momentos de desacuerdo, de salida del estado de equilibrio y de armonía:

Para los grupos, al igual que para los individuos, vivir significa desagregarse y reconstituirse sin cesar, cambiar el estado y la forma, morir y renacer. Significa actuar, luego detenerse, esperar y descansar, para volver a la acción, pero de otra manera (Van Gennep, 1996: 166).

La cultura, en general, y los fenómenos tradicional-mágicos, en particular, han contribuido a la salida del caos inicial y a la entrada en sociabilidad y normalidad, afirmando sus funciones modeladoras e integradoras. El individuo preocupado por el sentido del devenir de su ser, subordina su comportamiento a los modelos comunitarios, validados axiológicamente. El fenómeno sociocultural de lo mágico erótico está basado en normas tradicionales de comportamiento que tienen el papel de ordenar, dentro de una evolución coherente. De una experiencia a otra, el individuo recibe sugerencias y soluciones, a través de su permanente vinculación con modelos culturales, con estrategias verificadas en la práctica y apoyadas por mentalidades generadoras específicas.

1.2. Como acto bio-social fundamental, el matrimonio se propone - por medio de toda la ceremonia nupcial - recuperar las significaciones originarias del rito de la creación, para convertirse en auténtico y duradero. Lo matrimonial, en general, adquiere visiblemente el significado de una creación. La mitología autóctona de la unión familiar redescubre y reactiva su origen. En el plano cultural, las bodas del hombre sobrepasan la dimensión de lo social, aspirando a una boda universal, con profundas reverberaciones ontológicas, a una inclusión del matrimonio, según las normas milenarias del ethos, en una matriz de la existencia cósmica. En el ámbito comunitario tradicionalrural, el momento existencial centrado en el acto del paso matrimonial implica un modelo de comportamiento socio-cultural de las relaciones prematrimoniales y conyugales, imponiendo un sistema de reglas, convenciones y costumbres, prescripciones e interdicciones, asociadas a ciertas prácticas, técnicas y estructuras simbólicas, orientadas hacia la ordenación y el equilibrio de la vida, de acuerdo con la armonía universal.

El periodo prematrimonial, anterior a la edad adulta, está marcado por transformaciones físicas y psicológicas, de activación del instinto 
sexual y de intensificación de la vida afectiva. Este intervalo transitorio solicita múltiples acciones rituales, establecidas por medio de un código de comportamiento cultural-tradicional, con el fin de preparar el acto marital y pasar el umbral hacia la edad adulta, de existencia dentro de la pareja. El intervalo pre-marital está relacionado fundamentalmente con la búsqueda del compañero de vida, con vistas a la formación de la nueva familia, a través del matrimonio. El período preparatorio del cambio de estatuto social se caracteriza por una variedad de situaciones y estados reales o virtuales, de incertidumbres y expectaciones, de temores con respecto a la curiosidad de conocimiento anticipado del compañero. El intento de anulación de ciertas tensiones se realiza a través de la mediación cultural, recurriendo a un sistema de estrategias y técnicas mágicas que reflejan un modo particular de relacionarse con las cosas, de comprensión y de reconstrucción de la realidad.

Lo que confiere especificidad a las prácticas mágico-eróticas, que preceden el momento del matrimonio, es su carácter preventivo y anticipativo. Apelar a la función integradora y al modelo general del paso: separación-liminaridad-agregación, responde a la intención de prevención de una posible salida de la normalidad y al deseo de recuperación de la armonía y de la estabilidad, con respecto a una serie de prácticas rituales de anticipación del conocimiento del predestinado y de la captación mágica del compañero predestinado.

El proyecto cultural-tradicional, subordinado a los principios mágicos, propone un modelo de existencia que lleva a la idea de estabilidad. Por la acción e incidencia de las leyes ordenadoras de lo mágico, que facilitan la expansión de las aspiraciones humanas, se intenta rehacer la armonía y/o se previene el estado de crisis de las relaciones interindividuales en el ámbito comunitario de tipo ruraltradicional.

El hombre debe vivir como debe de ser, según los modelos tradicionales, mantener el equilibrio de las estructuras ontológicas, sin contradecir, por su comportamiento, el sentido común o las reglas de las relaciones interindividuales. Los tres momentos fundamentales: el nacimiento, el matrimonio y la muerte, se imponen como umbrales decisivos del proceso de integración en el mundo del hombre, con fines iniciáticos.

La mentalidad premarital está relacionada con la necesidad afectiva de amar y de ser amado, con el deseo exacerbado (sobre todo 
femenino) de afirmación de la individualidad, de lograr cierto prestigio en el grupo de edad. La competitividad y la tendencia exclusivista que se manifiestan en las relaciones sociales, sobre todo con ocasión de algunas manifestaciones importantes del período anterior al matrimonio («cuando una chica sale a bailar, cuando va a la feria, a una boda o a una fiesta»), justifican la atracción hacia ciertos hechizos, destinados a asegurar el éxito completo y la eliminación de la competencia.

Enfrentado a la pluralidad de las actividades prácticas de la existencia y al conjunto de reacciones actitudinales propias del modelo de comportamiento, el hombre llega a veces a una encrucijada, la ansiedad y los temores creándole una tensión que le conduce a las prácticas mágicas. La magia «es una posesión primordial del hombre a la que puede acceder sólo por tradición y que afirma el poder autónomo del hombre de crear las finalidades deseadas» (Malinowski, 1996: 119-120). La prolongación inquietante del período premarital y la postposición del momento del matrimonio más allá de las normas instituidas por la tradición, produce en la persona de los ámbitos folclóricos un estado interior conflictivo, el temor a una situación fuera de lo común. La tensión por sobrepasar la edad correspondiente, o más grave, por la imposibilidad de contraer matrimonio, defraudan las expectativas del medio comunitario al que pertenece. La incertidumbre, el deseo frustrado definen un estado de crisis en la relación del individuo con el grupo.

Cualquier anomalía frente a la costumbre con carácter de ley, fijada por la convención social y reforzada por la experiencia de vida comunitaria, y cualquier desviación del modelo tradicional, deben ser eliminadas, y el posterior intento de reequilibrio se hace por medio del acto cultural. Los fallos en la vida íntima y comunitaria motivan la orientación hacia las estructuras mágico-eróticas prematrimoniales, con la esperanza de colmar las deficiencias. El deseo amoroso, contrariado por la dificultad de establecer relaciones eróticas, por culpa de carencias físicas (especialmente fealdad) y/o psíquicas, o de una devaluación social, solicita la ejecución (performance) de unos textos poético-mágicos (hechizos) y de unos actos rituales, con vistas a reestructurar la identidad de la persona, a embellecerla y a valorarla socialmente. Frustrado socialmente, por rechazo e aislamiento, el individuo intenta, por mediación cultural-mágica, arreglar las relaciones interhumanas comunitarias, imponer su prestigio en el grupo al que pertenece y resolver las tensiones de conformación y adaptación a los modelos sociales y culturales. 


\section{FUNCIÓN Y EJECUCIÓN (PERFORMANCE)}

La magia es gobernada por un sistema de principios que dicta la manera en la que el acto debe ser ejecutado para que sea eficiente. El oficiante conoce los modelos, las estructuras y las técnicas mágicas, el conjunto de prescripciones y tabúes que se deben respetar para que la acción dé resultados. Cada ejecución se encuentra en el cruce de dos tendencias opuestas y complementarias, la libertad y la prohibición, este diálogo perenne entre «la predicción» instituida por las costumbres y la contradicción determinada por la multitud de los fenómenos existenciales contribuyendo decididamente a la salvación y mantenimiento de la autonomía y de la libertad de la persona.

Las estructuras mágicas ofrecen precisamente las leyes específicas y el marco de manifestación de esta casi libertad personal. Por muy fuerte que sea la fuerza de los modelos, la presión del sistema cultural asentado por la tradición, «los «modelos» («las normas») no «viven» al hombre, sino que siempre es al revés, el hombre utiliza y vive los modelos, dejando además, a cada momento, signos indicadores de su paso por la vida, por sus momentos definitorios. (Malinowski, 1996: 119 120). El hombre vuelve a cargar de significado los esquemas, a lo largo de la existencia individual y comunitaria. La ejecución implica lo estándar y lo no estándar, respetar los modelos, en relación con las representaciones mentales del patrimonio memorial arquetípico, pero al mismo tiempo la posibilidad limitada de afirmación del propio ser. La libertad relativa significa mantener un equilibrio necesario entre el factor normativo, impuesto por el código, y el factor de originalidad individual. Está prohibido sobrepasar el umbral de originalidad, que puede producir la ruptura violenta de la matriz modeladora. La prescripción interviene con función reguladora, de control, obliga a una vuelta al registro de la normalidad, armoniza poder y deseo. «La existencia entre los humanos reclama una ubicación estratégica de los hechos del hombre entre el polo subordinado a las leyes del ethos y el polo estimulante de la libertad de acción (que obligatoriamente, va a guardar una relación complementaria con lo admitido por la comunidad)» (Malinowski, 1996: 129). Como ser social, el individuo tiene la obligación codificada e, implícitamente, la libertad de accionar según las normas validadas por su comunidad.

Hay una permanente colaboración entre las evaluaciones psicocognitivas del individuo y el trasfondo de los moldes de comportamiento orgánicamente sedimentados en la cultura y civilización del 
ámbito comunitario. Por medio de las formas mágicas tradicionales, la motivación psicológica del individuo y su acto de voluntad personal, objetivados culturalmente, franquean el umbral de lo individual hacia lo categorial.

2.1. La actualización de la práctica mágica prematrimonial presupone dos situaciones esenciales: la ejecución especializada y la autoejecución. En ambos casos, la comunicación interhumana tiene también implicaciones sobrehumanas, por la invocación de la mediación sagrada, en busca del fin perseguido.

En el caso de la ejecución especializada (por una hechicera vieja, de costumbre), la acción pone de manifiesto la relación de comunicación interhumana, transitiva, entre el practicante y el solicitante. «En todas las tradiciones, en todas las mitologías, la magia estuvo siempre en posesión del hombre [...]. Ella concierne tanto al mago ejecutor como al objeto hechizado y a los métodos de hechizar» (Malinowski, 1996: 119). Los marcos tradicionales de la práctica mágica consignan apelar a una autoridad del ámbito comunitario-rural, reconocida por su competencia y por sus cualidades validadas en la acción.

En el caso de la autoejecución, la persona (el joven/la joven que hechiza), iniciado/a en las técnicas culturales y mágicas, es capaz de resolver por sí mismo/a sus conflictos internos y los que derivan de las relaciones de grupo o satisfacer una simple curiosidad prospectiva.

No pocas veces, los dos polos de la comunicación, la hechicera (papel especializado en el oficio ritual) y la persona (P) que solicita el hechizo, cooperan activamente en el acto de ejecución, alternando su actuación. Su parte no es igual, la persona especializada tiene en general mayor peso. En una variante de guión ritual premarital, el acto de traer agua recién brotada por la persona (P) que solicita el hechizo: Fata aduce nouă guri de apă, mută (la muchacha trae nueve sorbos de agua, muda) es seguido de una serie de actos rituales: și io le pui acolo-ntr-o strachină șî mă duc cu strachina aceia la horn, la gura sobii, șî pui frigarea în foc să se înfierbînte (y yo la pongo en un cuenco y voy con aquel cuenco al tubo, en la boca de la estufa, y pongo el pincho en el fuego para que se caliente) acompañados por la pronunciación del hechizo: șî descînt cuvintele aiestea (y digo estas palabras), efectuados por el especialista $(\mathrm{H})$. Después de tres tardes consecutivas en las que la vieja hechicera $(\mathrm{H})$ hechiza el agua, en su propia casa: $s \hat{\imath}$ tri sări apa șeia stă la mine (y tres tardes aquel agua está conmigo), la muchacha $(\dot{\mathrm{P}})$ recoge el agua de la hechicera: apăi ia vine șî-i dau apa 
seia (luego ella viene y yo le doy aquel agua) y la derrama en «tres cruces de camino». El acto inicial de traer agua «en la boca» motiva e impone, al mismo tiempo, según lo pide la norma, la intervención obligatoria de la solicitante $(P)$, en la ejecución. Al cooperar en la función, la muchacha $(\mathrm{P})$ se transforma en sujeto activo, directamente participativo, en contacto directo con la magia, reforzando el poder de la acción en el desarrollo del fenómeno.

En la unidad del conjunto cultural-mágico, la norma impuesta al ejecutor es purificación y pureza (la hechicera «tiene que ser limpia, limpia»), acentuando la finalidad del proyecto mágico en visión anticipativa. En algunas zonas del espacio cultural rumano, entre otras interdicciones que condicionan el éxito del fenómeno mágico figura la necesidad de que la hechicera «no sea viuda». Por contaminación mágica, el no respetar esta norma podría tener consecuencia nefastas sobre el futuro esposo de la muchacha para la que se realiza el hechizo (P): «no vive el marido de la muchacha que lo consigue» (Pamfile, 1998: 118).

2.2. La ejecución de las prácticas mágicas en su desarrollo sincrético atestigua el predominio de dos estados esenciales de lo femenino, la virginidad y la senectud, correspondientes a unos papeles con el emblema evidente de la pureza, que condiciona la eficacia del acto.

La mujer vieja, presente en la mitología popular como figura del ancestro mítico en línea femenina, tiene los atributos de la Diosa-Madre de la naturaleza y de la tierra reproductora. En la mitología del calendario, entre las festividades de las Viejas, la más conocida es la de la Vieja Dochia, celebrada el 1 de marzo, seguida por seis u ocho Viejas, que marcan la ascendencia del principio femenino en la vida de la naturaleza, de la sociedad y de la psicología individual.

En el hechizo erótico, la ejecución especializada se apoya en la competencia adquirida por la práctica y la experiencia acumulada, en el prestigio y la ascendencia en el ámbito comunitario: Și le făceam la multe. Da' veneau di pi la Valea Mărului și le făceam (Y se lo hacía a muchas. Porque venían desde Valea Marului y se lo hacía).

Las encuestas etnológicas sobre el fenómeno mágico atestiguan también la función de intermediario de la madre, que solicita la intervención del oficiante especializado, con vistas al matrimonio de su hijo o hija, con o sin la aprobación de éstos. Entre la hechicera que ejecuta el hechizo y la madre que se lo pide se establece una relación de intercambio. La oferta hecha por el acto de ejecución, equivalente a un ritual, con función simbólica, solicita la contra-oferta, el pago («la madre le paga a la 
hechicera»). Este principio de la reversibilidad sirve para equilibrar la interrelación, de acuerdo con las solicitudes del código. En algunas situaciones se produce incluso una sustitución de función, la madre actuando directamente si está familiarizada con la tradición mágica y con las solicitudes del código. Otras veces, la variación de función marca la contribución de la madre que le trasmite a la hija su experiencia, facilitándole el acto de ejecución: la muchacha «hechiza sola, a sabiendas de la madre y con su apoyo, que le facilita toda su práctica: «que digas eso, que hagas eso» (Pamfile, 1998: 118).

En los casos de autoejecución, las muchachas («la muchacha sin hechizar es como el jardín sin cuidar») (Pamfile, 1998: 118) son las que necesitan frecuentemente los hechizos prematrimoniales, conscientes de su destino en el acto de la perpetuación de la especie humana. La autoejecución masculina se recoge, esporádicamente, en algunas prácticas mágicas para conocer a la futura esposa: «incluso los muchachos, que quieren conocer a su futura esposa, después de cantar los villancicos por la aldea, van al tronco donde se corta la leña y se quitan toda la ropa. Luego entran en la casa, ponen la ropa debajo de la almohada $y$ en sueño conocen a la destinada» (Pamfile, 1998: 117).

La evolución de las estructuras mágicas premaritales atesta la imposición de la autoejecución de los actos ritual-mágicos y de los textos, con la consecuencia natural de la combinación de las funciones. En el desarrollo de la práctica mágica, la persona que recurre con confianza a las estrategias y a las técnicas tradicional-mágicas desempeña el papel de ejecutor (E), orientando su fuerza de voluntad y la intencionalidad hacia el acto, en el sentido de la realización o de la reestructuración positiva del destino del propio ser: es al mismo tiempo destinatario (R), comunicando y dirigiendo el mensaje hacia sí mismo, en una relación comunicativa reflexiva, y, por fin, beneficiario (B) de los efectos deseados.

La práctica tradicional mágica suscita el interés de la investigación también a través de los fenómenos específicos de sugerencia y autosugerencia, si tenemos en cuenta algunos estudios de parapsicología referentes a la existencia de múltiples tipos de acción psicoenergética: «Una de ellas consta de la apertura de la «esclusa» entre el consciente y el subconsciente, cuando la conciencia sigue, como desde afuera, a nivel no crítico, el proceso de sugerencia, tanto a nivel verbal, como a nivel no verbal» (Mamulas y Bianu, s.f.: 206). La habilidad en pronunciar ciertas palabras o en efectuar ciertos gestos puede asociarse a un estado de trance autohipnótico, provocado por distintos medios 
técnicos, desde la utilización de unas plantas alucinógenas como la mandrágora, exprimidas por masticación, hasta fumigaciones con semilla de cáñamo, o la repetición de ritmos sonoros obsesivos. La persona que realiza estas prácticas puede tener características innatas especiales, una vocación espontánea, una «cualidad adecuada», como la llamaría Gheorghe Pavelescu (1944: 12). Se ha dicho en algunas ocasiones que la magia se inscribe en el vasto complejo de los fenómenos paranormales (psicotrónicos) tan controvertidos. (Incluso un fenómeno ampliamente extendido como la hipnosis tiene todavía adversarios, porque el objeto de ésta no se deja atrapar en una escala de determinaciones ni a nivel psicológico, ni a nivel fisiológico o somático.)

La comunicación cultural entre los dos polos (hechicera y solicitante) pone de manifiesto las cualidades manifestadas en la ejecución, la personalidad del oficiante (convincente, emocionante), ligada a la retórica de la pronunciación y a la realización de los actos rituales, en relación con las disposiciones, el interés y la creencia del receptor.

La fuerza de la ejecución, la capacidad persuasiva varían según la calidad del practicante, según su capacidad de convencimiento en el papel, ya que la magia es el atributo del sujeto, reside «en el hombre, emanando [...] por su arte mágico, liberándose a la vez que su voz, transmitida por el acto ritual» (Malinowski, 1996: 120). Lo mágico no es sólo posesión humana, sino que está acumulado en la persona y puede ser manejado de una persona a otra, en función de las leyes de la filiación, de la iniciación y de la instrucción, previstas en el código tradicional rumano.

A diferencia del régimen restrictivo, característico del fenómeno en sus datos arcaicos, en el ejercicio cultural, el acto de iniciación parece haberse liberado progresivamente de tabúes. Como testimonio, hay informaciones auténticas en los fondos de archivo del Instituto de Etnografía y Folclore «C. Brailoiu» de la Academia Rumana de Bucarest, que hablan con toda claridad de la transmisión y el aprendizaje por solicitud: «En Puțãni, había una vieja, en aquel tiempo. Y hacía esto. $\mathrm{Y}$ yo fui y lo aprendí de ella». En algunas situaciones, la iniciación por comunicación y adquisición de las técnicas y de los modelos es selectiva: «venían las muchachas y se lo daba escrito, pero sólo a quien yo quería, no a todas».

El largo tiempo de la formación del individuo como hombre, del nacimiento hasta la muerte, es un trayecto del aprendizaje cultural, de 
la adquisición de las normas y de la experiencia sociocultural codificada. A lo largo de su existencia y su aprendizaje cultural comunitario, el individuo llega a dominar mentalmente el paradigma de las creaciones. «Según la visión folclórica, la noción de "trabajo", frente a la forma infinitiva "trabajar", ha evolucionado de manera distinta. [...]" Parafraseando el conocido aforismo griego, «el hombre es la medida de todas las cosas», podríamos decir que, desde una perspectiva etnofolclórica, la misma oración breve mantiene sólo el predicado, subjetivando el complemento, el trabajo, «trabajado», convirtiéndose en la medida fiel de la existencia humana. Pues, valorando su vida a través del trabajo de su espíritu y de sus manos, el hombre de la colectividad tradicional adquiere consideración social y autonomía opcional» (Crețu, 1998: 112). En esa modalidad de entrar y asentarse dignamente en la existencia, los jóvenes adoptan el comportamiento determinado por los principios del ethos comunitario. Aprenden los modelos de comportamiento socioculturales, y algunos adquieren incluso las estrategias mágicas preventivas, de verificación del trayecto existencial predeterminado y de intento de recuperación, por si se apartan del código. La evolución social y la modelización sociocultural del individuo se hacen por medio de la asimilación de los valores comunitarios.

El comportamiento mágico, manifestado en la estructura específica de comunicación vinculada a la estructura de función, conjuga la dimensión profano-utilitaria, relacionada con la finalidad concreta, con la dimensión sagrada determinada por la creencia en la fuerza de lo mágico objetivado en el pensamiento, palabra pronunciada y acto ritual, pero también por la creencia en una fuerza divina invocada frecuentemente, para la amplificación de la eficacia.

El desarrollo de los fenómenos mágicos tiene el valor de unos juegos simbólicos, con reglas y moldes propios, ofreciendo explicaciones, significados y un tratamiento cultural a su medida. La ejecución mágica aleatoria o, por el contrario, relacionada con cierto tipo de ritual en las grandes fiestas del año, muestra también la hipóstasis de homo ludens, relevante en general para todo el conjunto de manifestaciones culturales, con variaciones de una forma particular a otra. Por otra parte, por medio de las grandes fiestas relacionadas con la sucesión de las estaciones del año o con la evolución de la existencia, la humanidad «juega el juego» de la naturaleza, tal y como lo ha aprehendido en su conciencia. El aprendizaje de las prácticas mágicas es lúdico, y el hombre que recurre a ellas, sea directamente, por autoejecución, sea por mediación, con la ayuda de un practicante especializado, «no juega 
gratuitamente, sino que juega su vida adecuándola a los moldes de la cultura enraizada» (Cretu, 1988: 38).

\section{EL SINCRETISMO DE LOS LENGUAJES SIMBÓLICO-MÁGICOS}

En la configuración del fenómeno tradicional-mágico, la racionalidad justifica la forma conceptual, una manera específica de estructuración y una coherencia de sistema. Pero la razón no es el medio más adecuado para la comprensión del sincretismo de los lenguajes, que tienen un acentuado soporte afectivo, siendo testimonios del temor y de la desesperación, del deseo y del placer. Los lenguajes simbólicos, mágicos: verbal poético (los hechizos)-gestual (los actos rituales)-objetual (los instrumentos y las sustancias mágicas), oscilan entre el nivel subjetivo-emocional y el objetivo-racional, entre lo sagrado y lo profano, presentando una lógica fundada prioritariamente en la observación y en la experiencia, en la interconexión hombre-naturaleza-cultura. Comprendemos el universo simbólico-mágico en función de la configuración sincrética de los lenguajes, en relación con lo que Gaston Bachelard llama «imaginación material» y compartimos su opinión cuando dice que el simbolismo es un poder material (Bachelard, 1997: 138). Bajo el imperio de la «imaginación material», la realidad, representada de manera diferente en el universo simbólico de las estructuras mágicas, se convierte en espíritu y voluntad, apuntando a la variedad de los objetos y de las sustancias rituales, pero también a la diversidad de los componentes telúricos y cósmicos (sol, luna, estrellas, agua, tierra, fuego), invocados como hierofantes en apoyo a los actos mágicos.

Para el que vive dentro del universo creado, para el que recorre realmente las evoluciones de la imaginación material, el simbolismo tiene la dimensión de lo ontológico y las proyecciones mágico-míticas configuran otra realidad y otra forma de ser. Todos los sentidos que nosotros llamamos figurados desde la perspectiva del que está fuera, mantienen en la mentalidad del que se sitúa en el interior «cierta consistencia sensible, cierta materia sensible: todo el problema consiste en determinar esta materia sensible y persistente» (Bachelard, 1997: 149).

3.1. La transposición in actu, en la ejecución poética (la pronunciación del texto de hechizo) y poiética (la realización de los actos rituales 
con los instrumentos específicos), en la interacción sistémica de los lenguajes verbal-gestual-objetual, significa el paso de los paradigmas mentales del estado de latencia a un estado de manifestación, por medio de selecciones correspondientes a cada actualización del invariante.

«Quien habla comunica y se comunica», notaba Tudor Vianu en un estudio de estilística, remarcando que para todo el ámbito de los estudios estéticos y literarios, el lenguaje es «al mismo tiempo reflexivo y transitivo» (Vianu, 1973: 54). Por una adecuación al contexto de la comunicación mágica, poética (de los dichos, de los hechizos) y poiética (de los hechos, de los actos rituales), la interacción de los dos valores del lenguaje adquiere notas particulares. La reflexividad consta de la comunicación del yo consigo mismo y para sí mismo, y se relaciona con la transitividad comunicativa, con formas de dirigirse a otros. Considerado en «su doble intención», el lenguaje mágico, poético y poiético, se organiza en un conjunto de imágenes y procedimientos codificados, perpetrados por la tradición, a través de los cuales se realiza la comunicación transitiva, entre los miembros de la comunidad tradicional: del lado de la reflexividad comunicativa, el centro de sentimientos, deseos, motivaciones, decisiones que generan y perpetran funcionalmente las estructuras verbal-poéticas y práctico-rituales, les confiere el atributo de la subjetividad, un modo propio de sentir la existencia y de mantener el orden.

La función de comunicación solicita, necesariamente, la función de representación, lo que supone una adecuación del modo de formación de los textos mágicos a las estructuras del pensamiento. Los modelos poético-mágicos, combinados con los modelos poiéticos, representan la expresión de cierta concepción sobre el mundo y de un pensamiento imaginativo con notas específicas. Los actos mágicos son generados por la voluntad del ser humano sobre un trasfondo emocional particular. Aunque para una mentalidad positivista el fenómeno cultural mágico pueda tener un carácter ilusorio, como resultado de la función de la imaginación, para las sociedades tradicionales, rurales, representa una forma de ser, con sus leyes, en la que el hombre busca respuestas y soluciones a sus problemas vitales. La necesidad de estructuración, de afirmación y negación, de selección y certidumbre se concreta en formas propias de explicación y acción, resultados de la lógica de lo sensible. Para el hombre de la sociedad tradicional, en su relación con el ámbito social y natural, la magia es un adyacente de la vida, una mejor manera de adaptarse al medio ambiente, por medio del espíritu y se impone como guía suficiente —una Weltanschaung- y un arma existencial. 
Recordando con O. Ducrot que «la retórica es el arte de hacer triunfar la causa que defendemos» (Ducrot y Schaeffer, 1996: 111), observamos que los discursos y las prácticas mágicas sirven un fin y unas intenciones persuasivas. Lo mágico intenta provocar adherencia con la ayuda de lo emocional, produce una convicción que parte del soporte de la creencia. Por la acción del factor intencional, la oportunidad y las circunstancias de la ejecución de los lenguajes en su interacción se relacionan con la situación comunicativa, con los parámetros de tiempo y de lugar codificados,. La intencionalidad de los lenguajes pone en relación los dos papeles: $\mathrm{E}$ (el emisor) y $\mathrm{R}$ (el receptor), apuntando a la voluntad manifestada específicamente en los dos polos: la voluntad de ejecutar y la voluntad de recibir para beneficio personal.

La comprensión de la intencionalidad permite la matización de la relación entre la intención previa del emisor y del solicitante, y la intención en acto, concretizada en las construcciones textual-poéticas y en las actuaciones mágicas, en el proceso mismo de la ejecución. Los modelos poéticos y poiéticos revelan la orientación voluntaria de la utilización de unos procedimientos y estrategias retóricas, por el recurso a la fuerza mágica del pensamiento, de la palabra, del acto y del objeto. En el acto de comunicación, la función retórica de los lenguajes simbólico-mágicos sincréticos une el aspecto obviamente intencional de la ejecución con los aspectos intencional y de expectación de la recepción.

El arte de la composición del guión en su conjunto, en la interdependencia de los lenguajes, se realiza aceptando unas convenciones, unas restricciones y normas que configuran el código específico del fenómeno. Lejos de ser estándar, único, el modo de organización de la relación sincrética, de cooperación de los lenguajes, en relación con la estructura de función se diversifica, mostrando una diversidad de estructuras.

El conjunto del hechizo implica una relación de cambio cultural y un comportamiento comunicativo, con procedimientos de codificación y descodificación, suponiendo la existencia de unas instancias comunicativas, con manifestaciones específicas en la estructura de función. Aparece más evidente que nunca la necesidad de vincular el estudio poético (construcción interna de los textos verbales mágicos) y poiético (actuaciones mágicas), al estudio pragmático (relación entre los textos verbales, las prácticas rituales y los polos de la comunicación en una situación comunicativa determinada). El texto oral, como realización poética y poiética, no vive como tal más que en el contexto situacional de su actualización. En el libro Estructuras mágicas tradicionales 
(Coatu, 1998), consagrado a una posible interpretación del hechizo terapéutico, hemos dedicado un capítulo a la estructura de comunicación, partiendo de referencias generales sobre el fenómeno del hechizo y llegando a aplicaciones de las estrategias y las técnicas de exorcizar la enfermedad. Volvemos sobre algunas observaciones con carácter general, para relacionarlas, esta vez, con el modelo de la comunicación y con la estructura de función del hechizo erótico premarital. Nos mantenemos dentro de los límites de la misma visión, señalando que «la estructura de comunicación propia del sistema cultural del hechizo como objeto de cambio supone la transmisión y la recepción de los mensajes con su funcionalidad, en un marco interdiscursivo que implica la presencia de las instancias comunicativas (el practicante y el receptor), en un contexto situacional característico, en conformidad con el código propio, factor de restricción esencial en la construcción de los mensajes, en la ejecución y en la descodificación. En una situación comunicativa específica, [...] la comunicación de los mensajes cultural-mágicos se produce cuando los códigos y los repertorios de los dos polos de la comunicación, el practicante y el receptor humano, son comunes. Mencionamos que se trata de un código y un repertorio bien establecidos, consolidado por tradición» (Coatu, 1998: 16). Al relacionarse con las restricciones de su código, el hechizo erótico, producido en el conjunto sincrético del acto de hechizar, tiene modelos específicos y rasgos estilísticos particulares, aplicados a cada variante in vivo.

La creatividad del ejecutor se manifiesta por la virtuosidad con la que éste realiza variaciones sobre los esquemas temáticos y formales, actualizando los modelos que constituyen un bien comunitario. El proceso de «rememoración generativa» (Ducrot y Schaeffer, 1996: 401) se refiere fundamentalmente a los modelos que representan el nivel de la estabilidad relativa.

La memoria colectiva retiene lo que corresponde a las exigencias comunitarias socioculturales. Sobrevive sólo lo que goza del aprecio y de la validación colectiva, implícita, individual. La magia, al ser creada por el hombre para el hombre, la creencia en ella significa la afirmación del poder del ser humano para determinar ciertos efectos por la interacción de los lenguajes (haciendo de éstos un instrumento de comunicación y de significación, con una finalidad determinada) con la estructura de función propia al fenómeno. Los actos rituales, las sustancias y la indumentaria, los gestos y las expresiones del ejecutor, las declamaciones poético-mágicas generan un marco emocional con el fin de sugestionar al interlocutor. A medida que la tensión 
se consume en el conjunto de actos y de imágenes comunicados textualmente, el final deseado, expresado por el hechizo, trae la satisfacción, la confianza, la idea de equilibrio recuperado, en armonía con la vida.

Los lenguajes mágicos respetan la regla fundamental del símbolo cultural, el cual, «después de haber impuesto la vida ante la muerte, el buen sentido del equilibrio ante el trastorno psicosocial, instituye el principio de los valores humanos supremos ante la entropía positiva del universo» (Durand, 1968: 112).

El pensamiento y la palabra pronunciada producen relaciones y significados nuevos para la mentalidad que los genera. El texto poético-mágico dispone de un poder intrínseco, existe como sustancia y energía transformacional, creadora de valores. Con la intención de poner de manifiesto el papel del discurso mágico en el conjunto del fenómeno, algunos teóricos han estimado — quizá exagerando-que «el elemento más importante en la magia es el hechizo: [...] el ritual está centrado alrededor de la pronunciación del hechizo. La fórmula es siempre la esencia de la ejecución mágica» (Malinowski, 1996: 115). En todo caso, el texto mágico es generador de estados y cualidades nuevos, constituye en la misma medida un instrumento eficaz subordinado a la intención y a la voluntad, y una causa del cambio deseado. Manifestado en y por la palabra, pero también más allá de ésta, el pensamiento se instituye como un lenguaje casi autónomo que apoya la función retórico-mágica. El pensamiento es el soporte íntimo de la intencionalidad, provocando la dinámica de todo el fenómeno.

El texto poético declamado coopera frecuentemente con el silencio, que tiene la significación y la fuerza de un lenguaje y al mismo tiempo la autoridad de una prescripción codificada. La ausencia de la palabra, y la concentración al nivel del pensamiento, suma un potencial espiritual que refuerza la voluntad de manifestación en el acto.

La fuerza de los actos y de los textos poético-mágicos se relaciona con la fuerza psíquica del hombre, con el conjunto intelectivoafectivo-volitivo, por medio de la intencionalidad en la manifestación concreta. La retórica de los lenguajes, de los textos poéticos y de los actos rituales interaccionan con la retórica de la ejecución, con los componentes expresivos del dicho (capacidad verbal, ritmo, entonación, modulaciones de la voz) y con los elementos de elocuencia corporal. 
3.2. En el sincretismo complejo de los lenguajes simbólicos, las significaciones de los textos son reforzadas por la polisemia de los actos rituales, que se convierten en métodos de movilización, canalización y control del comportamiento humano, actos o series de actos formales o convencionales, ordenados en un desarrollo estereotipado. Asociados a los actos rituales, los objetos rituales y las sustancias, con sus afinidades, con las relaciones de similitud y contagio, reciben, retienen, transmiten la fuerza mágica, la captan y la mantienen para luego aplicarla donde se quiera. En la interacción de las declamaciones poéticas y de los actos rituales, con instrumentos propios, las significaciones se interpenetran, se apoyan mutuamente y se enriquecen, acentuando la funcionalidad y las oportunidades de éxito, en el contexto de la mentalidad comunitaria tradicional.

Las relaciones temporales entre la realización de la práctica ritual y la ejecución textual varían de un caso a otro, marcando la simultaneidad de los actos y de los dichos discursivos o la anterioridad/posterioridad de la praxis frente a la poesis. Estas relaciones apuntan al aspecto sintagmático de los lenguajes sincretizados frente a la dimensión temporal, en la concreción del desarrollo del fenómeno mágico. De modo complementario, el desarrollo del conjunto (praxis y poesis) se hace en relación con el tiempo cualitativo, situado fuera de la duración y de las relaciones de anterioridad-posterioridad-simultaneidad, por referencia a un presente eterno.

Los sincretismos presentados a continuación atestan sólo algunos aspectos de la interacción de lo poético con lo poiético, con especial referencia a la situación en la que los textos presentan un contenido homólogo en la praxis ritual. En este caso de homologación ritual-poética, los hechizos comentan, transfiguran en su diversidad configurativa, los componentes del ritual, reforzándolos y diversificándolos semántica y retóricamente.

Facerea cu ulcica (el uso del cazo) ${ }^{1}$, uno de los más usuales y extendidos hechizos, supone un guión simple, con la realización de tres actos mágicos relacionados con dos objetos rituales:

- Poner el cazo utilizado boca abajo: «coge un cazo y ponlo boca abajo».

1 Facerea cu ulcica significa «hacer hechizos». Se emplea la traducción mot à mot para explicitar la ejecución del hechizo (N.T.). 
- Poner sobre el cazo unos trozos de carbón.

- Dar vueltas al cazo con los trazos de carbón, acto acompañado de la ejecución del texto.

El cambio de la posición del cazo tiene un evidente valor simbólico, por la prefiguración de la intención de transformación del estatuto social por el matrimonio, teniendo en cuenta la información misma relacionada con la manifestación en función y con la autoejecución realizada selectivamente: «lo hacen sobre todo las muchachas que no se pueden casar» (Floarea-Marian, 1893: 49-50). La simultaneidad del gesto ritual y de la ejecución del hechizo implica la explicación discursiva de la relación entre el sentido propio y el sentido figurado-simbólico del acto de rotación del objeto. Al negar la realización del gesto en sentido propio: «Yo no doy vueltas al cazo», el texto poético llama la atención sobre la significación simbólica, descifrando —en la rotación del objeto- el correspondiente, en sentido figurado, de la vuelta del amor del joven (N.), «de otras muchachas», hacia la persona que le desea, con vistas al matrimonio: Ci-ntorc gîndul/Și cuvîntul/Și inima lui N./Cu totul/De la alte fete spre mine (Y vuelvo el pensamiento/y la palabra/y el corazón de N./completamente/de otras muchachas hacia mí).

La retórica mágica impone el desarrollo poético de la finalidad de la ejecución, la explicación y la descripción de las expectativas de la muchacha, en la proyección específica de las estructuras mágico-eróticas: Să par din față/Cuconiță,/Iară din dos/Păuniță (Que me parezca de frente a una señorita,/y de espaldas, a un ave del paraíso).

La intención de modificar la actitud del compañero elegido («N») y nombrado obligatoriamente en el texto, para acentuar la unicidad de las relaciones eróticas, produce —en la lógica del discurso mágicouna extensión hacia la relación con el grupo de edad (masculino), con la sugerencia de un efecto de aumento cualitativo («todos me van a alabar»), por la combinación del principio de la singularización con el principio mágico de la totalidad, en el mismo plano ideal: Cît ti în urmă mi-or călca/Toți m-or lăuda,/Cu dînșii oi juca,/În gură m-oi săruta,/De mînă că m-or lua,/Cu dînșii m-oi dezmierda (Cuantos detrás me irán,/Todos me van a alabar,/Con ellos voy a bailar,/En la boca nos vamos a besar,/Los que la mano me van a coger,/Aquellos me van a acariciar) (Floarea-Marian, 1893: 49-50).

La misma forma de estructuración, relevante para la correspondencia entre el acto ritual y la expresión del texto poético, se descifra tam- 
bién en una versión en la que la praxis ritual implica la relación con una parte del cuerpo, reforzada semánticamente por la combinación numérica: «soplas tres veces sobre los hombros, nueve veces sobre los dos». A diferencia del caso precedente, la ejecución del texto es posterior al desarrollo de los actos: «y luego, dices nueve veces». El texto niega el sentido propio del acto, en relación con el plano referencial: «No soplo encima de mí», con la intención de afirmar un sentido figurado-metafórico, en un universo imaginario: «Y soplo en un molino», para construir, consecutivamente, el efecto amplio explícito. Desde la impresión superlativa generalizada, producida por la imagen reestructurada de la persona frente a su ámbito social, en una recogida de la totalidad: «Quien me vea/que se muera./O joven/O viejo/O viajero/del camino», la estrategia discursiva recurre al efecto retórico del contraste, seleccionando, por singularización, la imagen del compañero nombrado, con la enumeración progresiva del cambio de actitud, del interés máximo manifestado hacia la persona inicialmente ignorada: «Más fuerte Fulanito/que se muera/que reviente/conmigo que hable» al acto del noviazgo: «Conmigo se comprometa». El hechizo anuncia, como un proyecto, el acto marital: «Y conmigo se case».

La interdependencia praxis-poesis se manifiesta, en algunas versiones, por una correspondencia realizada segmento por segmento, en el desarrollo del guión mágico. En una versión de «traer al predestinado», el primer momento coincide con dos actos rituales efectuados por el practicante en la persona que solicita el hechizo: la eliminación de la vestimenta y la atadura de los pies de la persona $(P)$ sentada en medio de la habitación donde se ejecutan los actos rituales: «lo despoja, lo pone desnudo o desnuda en medio de la casa, hacia la puerta, le ata los pies» (Teodorescu, 1985: 54). La práctica mágica impone la cooperación de los dos papeles: del practicante (D) especializado y de la persona que solicita y recibe el hechizo (P). La condición de participación del solicitante (P) («muchacho o muchacha») basada en el plurisemantismo de la desnudez asocia otros tres aspectos esenciales del momento, que refuerzan el espectro connotativo:

a) Uno, con directa referencia a la persona hechizada (P), concierne el acto de la atadura de los pies, con la intención de crear una doble relación análoga. En un sentido, el gesto produce una equivalencia mágica entre la imagen de la persona y la de un caballo de pies atados, el acto siendo sostenido por la manifestación sonora de la persona $(\mathrm{P})$, cuyo papel pide que reproduzca el relincho del caballo: «que relinche 
como los caballos» (Teodorescu, 1985: 54). En el otro sentido, vinculado al primero, la atadura de la persona produce, por analogía mágica, la atadura simbólica de la pareja, como posesión y dominación.

b) y c) Los otros dos aspectos apuntan prescripciones codificadas de espacio y tiempo. El tiempo de la ejecución ritual: «antes de que cante el gallo» (Teodorescu, 1985: 54), es el tiempo de la noche, hasta el alba, un momento favorable a la fuerza de manifestación de lo mágico. Al igual que en otros hechizos, se invoca también el simbolismo del centro, en la representación del centro de la casa. En este registro de las interferencias sagradas y profanas, la casa, como espacio consagrado, posee las connotaciones de un centro, que polariza las energías. En general, la implicación de la casa como espacio esencial en el desarrollo de las acciones rituales es posible e incluso necesaria, ya que «la casa es la materialidad misma de la familia, de esta unidad social que, con razón puede ser considerada la célula engendradora de la colectividad. No solamente desde un punto de vista espacial, en superficie, sino también desde uno temporal, en profundidad, la casa y su lugar tienen un trasfondo moral que nuestro mundo urbano ya no guarda» (Bernea, 1997: 33). La ubicación en una especie de centro del centro (el centro de la casa), con la sugerencia de una focalización progresiva, induce el semantismo de la interioridad y de la posesión.

El segmento textual relacionado con todos estos elementos que marcan el nivel de la praxis, de las funciones, del espacio y del tiempo de la ejecución, se compone como una fórmula con dos versos: Frunză verde de alun,/Să vie Cutare nebun (Hoja verde de avellano,/Que venga Fulano loco). El incipit estereotipado «Hoja verde» indica una relación intertextual del hechizo con el texto lírico propiamente dicho. La presencia del avellano parece ser más una necesidad de la rima, que una alusión a un objeto ritual (la rama de avellano) frecuente, de hecho, en las prácticas mágicas. Pero no excluimos tampoco la posibilidad de ambas motivaciones, como aspectos complementarios, en planos diferentes y relacionados: formalmente y semánticamente. El segundo verso contiene tres elementos: el subjuntivo con valor imperativo, que introduce también el deseo mágico de traer al amado ( Que venga»), el nombre de éste («Fulano»), adecuado a cada ejecución del texto, y el atributo con valor estilístico de epíteto que define el estado del compañero («loco»), en la visión transformadora del texto mágico.

Después de ser preparada por el practicante para asumir su papel, la persona $(P)$ que espera el hechizo reacciona según el modelo preesta- 
blecido, «saltando tres veces hacia la puerta, relinchando como los caballos» (Teodorescu, 1985: 54).

El sincretismo de los lenguajes interfiere con el sincretismo de las funciones. Mientras el solicitante del hechizo (P) realiza sus actos, se produce también la ejecución, por parte del practicante (D), de una secuencia discursiva que desarrolla la imagen del compañero deseado. El contenido pronunciado significa -en el determinismo mágico- el contenido cumplido. Ésta es la función del subjuntivo imperativo que proyecta la esperanza y ordena su realización: Frunză verde,/Lemn de fag/Cutare să moară/De-al tău drag (Hoja verde,/Madera de haya/Fulano que se muera/Por ti).

La repetición del acto, del triple salto hacia la puerta, con la imitación del relincho se hace a la vez que se ejecuta otro segmento discursivo que pone de relieve la imagen de la pareja, al retomar el nombre y al mencionar una característica que induce la idea de armonía posible en la pareja: Frunză verde/Lemn de sînger,/Să vie Cutare/Ca un înger (Hoja verde,/Madera de cornejo,/Que venga Fulano,/Como un ángel).

El avance como gesto realizado por la persona $\mathrm{P}$ se hace de la misma forma «hasta el umbral de la puerta, donde se cae en el suelo» (Teodorescu, 1985: 54). La detención delante de la puerta tiene un valor simbólico, sugiriendo - anticipadamente- el paso. La simulación de la caída por la acción de función de la persona (P) se circunscribe al mismo mecanismo analógico-mágico que tiene que ver con la unidad de la pareja. Por medio del gesto ritual-simbólico de la caída, al igual que por el de la atadura de la persona se intenciona, por analogía, la transferencia al compañero, en el sentido de la dominación de éste.

Las dos funciones implicadas en la ejecución alternan: la persona (D) que ejecuta «salta, corta la atadura con un hacha», mientras que el solicitante (P) se reincorpora a la acción: «se levanta el desnudo, rodea tres veces la casa» (Teodorescu, 1985: 54). La acción de rodear la casa es un modo de figuración simbólica del círculo mágico, significando separación y protección, pero también atrapar. En este último sentido simbólico, la casa rodeada asocia la imagen del compañero determinado, por hechizo, a responder a la demanda erótica. La pronunciación de la llamada es simultánea al acto del rodeo de la casa. La retórica del texto mágico es acentuada por el carácter gritado de la ejecución («grita los versos»): Cutare, nu zăbovi,/Scoală-te,/Nu mai dormi!/Vin 
de grab»/Că te-oi iubi (Fulano, no te entretengas/Levántate,/No duermas!/Ven de prisa/que te voy a amar).

En el desarrollo de la praxis, la persona $(\mathrm{P})$ que ha solicitado el hechizo «entra en la casa, se viste, se arregla», y cogiendo «un palito en la boca, se pone de pie sobre la boca de la chimenea» y vuelve a pronunciar un segmento de texto, por el que acentúa la llamada de la pareja hacia el amor, también en una triple performación («y dice tres veces»): Frunză verde/Dirmitin/Cutare, vin/Să ne iubim! (Hoja verde/Dirmotin/Fulano ven/A que nos amemos). El guión ritual continúa bajo la forma de la autoejecución, con el predominio de la acción de función de la persona (P) que «sale fuera, ata un palo y cuenta hacia adelante 50 palos». El palo número 50 y el último donde se detiene se convierte en el homólogo simbólico de la pareja. Los gestos de cariño hacia el palo: «lo envuelve entre los brazos, lo besa», y las palabras pronunciadas simultáneamente, incluyendo obligatoriamente el nombre de la persona amada, concurren en descifrar el sentido simbólico: Foaie verde,/Mărgărit,/Pentru tine m-am gătit!/Hai, Cutare,/Pui boboc,/Nebun să vii/La acest loc (Hoja verde,/Margarita/Para ti me he arreglado/, Ven Fulano,/Pequeño/Como loco/A este lugar!» (Teodorescu, 1985: 54).

En algunas prácticas mágicas se impone respetar una condición considerada esencial a la hora de obtener la eficacia de la intervención, es decir, la norma de evitar el contacto humano con la persona que ejecuta (P), o bien verbalmente: «que no hable con nadie», o bien visualmente: «sin que alguien la viera» (Floarea-Marian, 1893: 106). Los estudios de simbología comentan el silencio como símbolo de la evasión de la duración, representando - en general - una vía de iniciación, un intento ascético, de renuncia a la tentación de la exteriorización y, a veces, de renuncia parcial a la vida. En el baile de los calusari $^{2}$ existe un personaje llamado El Mudo, que muere y resucita, simbolizando la fuerza viril, la vida que vuelve a empezar con la llegada de la primavera. Aunque todos los călușari están bajo un juramento de silencio, sólo El Mudo no puede hablar e intenta hacerlo, porque él representa la fuerza aún no nacida, irracional de la naturaleza.

En las prácticas premaritales debe ser respetada la prescripción de aislamiento e incomunicación verbal con los demás para que el hechizo tenga efecto, el no respetar el código tiene como consecuencia un fallo.

2 Baile popular rumano ejecutado por jóvenes varones en la semana posterior al Corpus Christi (50 días después de Pascua de Resurrección). 
Por ello, al mantener la relación con el código y con el modelo, la persona que pronuncia el texto procura «que no haya nadie en la casa que pudiera oírla y molestarla a la hora de practicar el hechizo. Si alguien estuviera en la casa y la viera hacerlo, entonces todo el hechizo, según su creencia, no tendría ningún efecto» (Floarea-Marian, 1893: 33).

La interdicción de tener contacto visual o auditivo con otro ser humano está relacionada frecuentemente con la realización de un trayecto (por ejemplo, desde la casa hasta una fuente y de vuelta). En algunas variantes el silencio condiciona el recorrido del camino en ambas direcciones; en otras versiones, la prescripción codificada del silencio se aplica en una sola dirección, con la supresión del tabú en la vuelta («cuando vuelve, la puede ver quien sea, porque entonces no le afecta en absoluto») o al contrario, con la introducción de éste en el momento de la vuelta («vuelve a casa procurando al mismo tiempo que nadie la vea») (Floarea-Marian, 1893: 109).

En las prácticas de «atraer al futuro esposo» («las muchachas de Moldavia, municipio de Suceava, que quieren casarse, la noche anterior a la festividad de San Basilio, si el cielo está despejado, se cogen la falda y el cinturón en la mano, y miran una estrella luminosa») (Floarea-Marian, 1994: 96) se realiza una triple ejecución de un texto de invocación del objeto ritual, el cinturón, utilizado simultáneamente en un acto por el que se solicita la implicación de la fuerza astral, en beneficio del hechizo: «arrojan sin cesar el cinturón hacia la estrella». $\mathrm{El}$ acto simbólico ascensional por el que se persigue captar las energías cósmicas mediadoras es amplificado funcional y semánticamente por la invocación de la estrella. El segmento invocatorio es seguido y reforzado por un acto con múltiples significados: arrodillarse tres veces, en dirección a los cuatro puntos cardinales. Integradas al sincretismo ritual erótico, las significaciones de la tríada unificadora, dinámica y productiva, encuentran y aumentan las connotaciones de la tétrada representada por los puntos cardinales, expresión simbólica de la totalidad y de la plenitud, de la armonía y de la estabilidad en la unidad y solidaridad humano-universal.

El siguiente momento, el de la entrada en casa, se hace con «los ojos atados o solamente cerrados» (Floarea-Marian, 1994: 96). La regla del silencio y, en general, de la interdicción de comunicación, se relaciona frecuentemente con tapar los ojos, lo que indica la ruptura de nivel, el aislamiento de lo profano y la vivencia temporal en el registro de lo sagrado. «Los que pierden la capacidad de ver las formas exteriores, fugitivas y engañosas», comenta Ivan Evseev, «adquieren la facultad 
de una "vista interior", se convierten en los dueños del mundo espiritual, de la sabiduría de los ancianos, de la clarividencia sobrehumana. Los hechiceros, los profetas, los poetas (Homero), los visionarios son a veces ciegos» (Evseev, 1994: 34). Los que hacen predicciones son generalmente ciegos, como si se tuviera que tener los ojos cerrados ante el mundo físico, con el fin de percibir la luz divina. El ciego evoca la imagen del que ve otra cosa, con otros ojos, algo que pertenece a otro mundo. La ceguera (considerada a veces como un castigo divino) está relacionada también con las experiencias iniciáticas. En todas las tradiciones, mitos, costumbres, el simbolismo del ciego es ambivalente, oscilando entre bueno y nefasto. El lado positivo del simbolismo de la ceguera se refleja en que el ciego se une a la divinidad, es inspirado, y, a la vez, es poeta, taumaturgo y visionario (Chevalier, Gheerbrandt, 1994: 383).

\section{EL DISCURSO POÉTICO-MÁGICO: ACONTECIMIENTO Y SIGNIFICACIÓN}

El hechizo es «acontecimiento» 0 «instancia de discurso» (utilizando el sintagma propuesto por E. Benveniste), por medio de su propia producción, en el presente de la ejecución. El texto como productividad hace referencia al locutor, por medio de unos indicadores (a los que vamos a hacer referencia a continuación, siguiendo aspectos referenciales). El discurso como «acontecimiento» solicita la presencia de un ejecutor que produce la variante. El discurso mágico construye un universo, se refiere siempre a algo: a un mundo al que pretende describir, expresar o representar. La formación del texto mágico en la oralidad implica también el polo de la recepción, el diálogo con un interlocutor. Este modelo que señala la interacción de los cuatro factores:

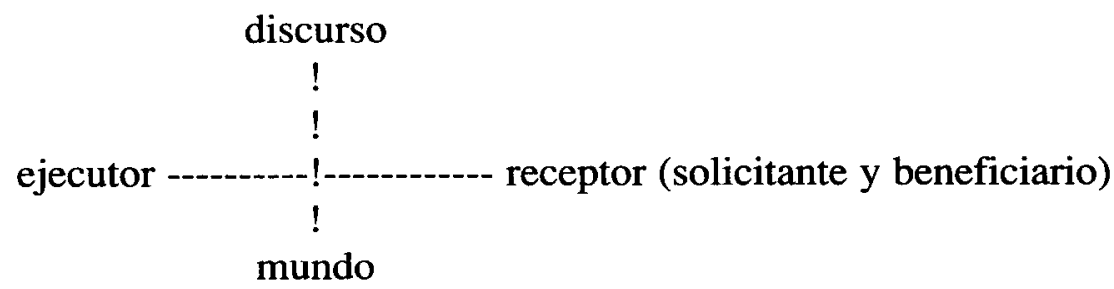

se objetiva en el acto de ejecución, en la actualización de la competencia. 
Integrado en la estructura de comunicación, el texto poético instaura un tipo particular de relaciones entre las instancias comunicativas, construyendo con necesidad, por determinación funcional, cierta imagen correspondiente a la persona $(\mathrm{P})$ que solicita el hechizo, lo recibe y se beneficia de sus virtudes transformadoras. Correlativamente, la comunicación mágica implica también a la pareja sobre la que se acciona y así las estrategias poéticas construyen obligatoriamente también la imagen de la pareja destinada que se debe activar, sensibilizar por la fuerza de lo mágico, para responder a la llamada erótica inmediata, pero también a las llamadas más lejanas en un futuro, relacionadas con la perspectiva del matrimonio. El hechizo pone de manifiesto también una relación particular - matizada de una variante discursiva a otra - con el polo del emisor (D-ejecutor), con resoluciones distintas impuestas por las dos situaciones específicas de la estructura en función, mencionadas anteriormente. Apelar repetidamente a los receptores sobrehumanos, a la mediación de unas fuerzas divinas y demoniacas, para aumentar las posibilidades del texto mágico y del fenómeno, en conjunto, abre la comunicación cultural hacia la zona de lo sagrado. Lo mágico, lo mítico y lo religioso, sincretizados, explican la ubicación del texto poético en un plano de la transliteraridad.

La comprensión del hechizo como acto discursivo persigue también el aspecto intencional del texto relacionado con su finalidad y la del fenómeno entero. El texto poético mágico como cualquier otro acto de lenguaje es la realización de «una voluntad de decir» del locutor, que, para ser comprendida, debe ser reconocida como tal por el receptor. El factor intencional pone, por lo tanto, en relación toda la red de comunicación, fundamentando la organización del texto, los componentes estructurales internos, la semántica, las técnicas y los procedimientos retóricos. El análisis de las significaciones de un texto mágico no se cumple sólo por referencia al contenido intrínseco, sino también por el tipo de relación que su uso instituye entre los polos de la comunicación.

Los hechizos son actos discursivos y, por lo tanto, la dimensión verbal debe estar inscrita en el contexto más amplio de la comunicación. La situación de discurso representa el conjunto de las circunstancias en las que tiene lugar la enunciación, y ésa engloba el marco físico y social en el que se produce la ejecución, la imagen que los interlocutores tienen sobre la enunciación, la identidad de éstos, la idea que cada uno se hace del otro (incluida la representación que 
cada uno tiene con respecto a lo que piensa el otro de él), los acontecimientos precedentes a la enunciación (especialmente, las relaciones entre los interlocutores y las interacciones precedentes verbales en las que se inserta la enunciación). En una dirección, la pragmática misma «es definida a menudo como el estudio de la influencia de la situación sobre el significado de los enunciados» (Ducrot y Schaeffer, 1996: 492).

El factor situacional se añade desde fuera a la significación del texto, para producir, ulteriormente, el sentido del enunciado. Pero, frecuentemente, en el texto mágico el practicante tiene la posibilidad de designarse a sí mismo recurriendo a la situación de discurso y al hecho de que es él quien ejecuta, diciendo yo, y designa al destinatario con el pronombre tú o con la sustitución del pronombre por el nombre de la persona (marcado, en las variantes escritas, por «Fulano», por las iniciales: «M», «N», etc.). Los efectos situacionales de un texto cambian y se matizan de una versión a otra. Dicho de otra manera, un hechizo-versión significa una objetivación del modelo en una situación de discurso. Una serie de elementos informativos del discurso envía a la situación, pero el texto la reinterpreta, la recrea, proyectando su propia situación de discurso. «Uno de los problemas esenciales de la pragmática es determinar las relaciones entre estas dos situaciones, interna y externa al enunciado, y ver cómo interviene la segunda en la construcción de la primera, y el modo del que las dos interfieren en la interpretación del enunciado» (Ducrot y Schaeffer, 1996: 497).

Todo discurso mágico producido como acontecimiento es comprendido como significación. Al articular el acontecimiento y la significación en la hermenéutica del hechizo, observamos que el discurso se supera como acontecimiento en la significación, atestando la intencionalidad misma del fenómeno.

Interpretamos las estructuras verbal-poéticas como un conjunto de actos subordinados, distribuidos en tres niveles:

- El nivel del acto de locución (la declamación de la versión).

- El nivel del acto o de la fuerza de ilocución, indicando lo que se hace al declamar.

- El nivel del acto de perlocución, con la mención de lo que se hace por el hecho de que se ejecuta. 
El texto mágico como acto locutorio consta de su producción como versión en el acto de la ejecución, por medio de la articulación y la combinación coherente de los componentes, según una lógica interna y por medio de normas previstas en el código propio.

La declamación del texto como acto ilocutorio está relacionada con la intención del que ejecuta de modificar la situación de una persona, de una pareja, bajo el imperio de la creencia, de la voluntad y del deseo. La fuerza mágica hace que el destinatario se someta a la orden dada por el texto dicho, que responda a una advertencia o a una interrogación que provoca el ofrecimiento de una solución. La dimensión ilocutoria del hechizo construido en el acto de la ejecución reside en que el texto da una información, hace una promesa, expresa una amenaza, una recomendación o un deseo. El texto mágico implica una fuerza ilocutoria asertiva, imperativa, optativa, invocativa, indicando el tipo de acto al que le es destinado el enunciado: pregunta, orden, solicitud, aserción, relacionado con diversas actitudes.

Por su naturaleza y funcionalidad mágicas, el hechizo se impone como acto perlocutorio, con valor de acción. La dimensión perlocucional hace del discurso mágico erótico un instrumento, un estímulo y una causa con las consecuencias deseadas, precognitivas y transformadoras, relacionadas con el acto marital.

En sentido psicológico, el texto mágico producido oralmente, dentro de la estructura de comunicación propia del fenómeno sincrético, actúa de manera energética, influenciando directamente las emociones $\mathrm{y}$ las disposiciones afectivas del interlocutor.

La poesis mágica es performativa por su calidad de proponer la transformación de la realidad. Además de los textos performativos explícitos, que contienen una interrogación, una orden, viendo el cambio deseado, se observa también la presencia de unas variantes discursivas de forma declarativa, que a pesar del aspecto constatativo, tienen un valor performativo, con la misma finalidad: modificar el estado de hecho. Explícita o implícitamente, un texto construido sobre el principio de la fuerza activa (mágica) de la palabra pronunciada, no puede ser una simple representación de un acontecimiento, la acción efectuada a través de la palabra estando ya indicada al nivel de la significación. Los textos constatativos, en forma narrativa o enumerativa, poseen, a su vez, valor de acción, similar al de los discursos performativos. En la ontología del texto mágico, la afirmación de unos acon- 
tecimientos presentados en una sucesión (narrativa) provoca la modificación del estado de la persona.

La hermenéutica persigue las modalidades de generación y los mecanismos de funcionamiento del texto mágico, partiendo del principio de que la estructura está subordinada a la funcionalidad.

La función metalingüística (R. Jakobson) del texto mágico define la permanente referencia al sistema propio de reglas que configura el código. La obligación de respetar las normas, las prescripciones y las interdicciones, a todos los niveles, es una condición de la existencia misma del texto, de su producción.

El estudio contextualizado del texto oral-mágico, integrado en el conjunto sincrético del hechizo, en relación con la estructura de comunicación y con la estructura de función, concierne también su función expresiva (R. Jakobson), con el relevo de dos aspectos, uno relacionado con la retórica de la ejecución y otro con un conjunto de modalidades específicas de significación de unos estados psicológicos. La declamación del texto se hace con variaciones de entonación que comunican estados emocionales, con ciertas modulaciones de la voz combinadas con la rítmica del decir. La experiencia de la comunicación discursiva es vivida como institución de unas relaciones sociales y afectivas. Los textos expresan estados emocionales asociados con la esperanza y la confianza en los efectos de la magia. Los hechizos contienen palabras-clave, con una carga emotiva que invoca, afirma $u$ ordena, libera el deseo y anticipa el final. El carácter fundamental dinámico, transformador del lenguaje poético-mágico, reside también en la sinceridad orgánica de las imágenes, en su fuerza de evocación y en asumir una actitud activa. La tensión psicológica liberada da fuerza a las palabras y a los actos, orientándolos hacia un fin obvio.

La multifuncionalidad del discurso mágico apunta a la manifestación de la función conativa ( $R$. Jakobson), referente sobre todo al polo de la recepción, a la hipóstasis del que recibe el mensaje transmitido por comunicación oral. La función del receptor se diversifica en el conjunto de la acción mágica. En el acto concreto de la ejecución, el intérprete/emisor se comunica, por medio de los lenguajes simbólicos sincretizados, con el receptor humano, solicitante, pero al mismo tiempo beneficiario de la intervención mágica. Los textos poéticos sostenidos por las prácticas rituales, en la unidad del sistema, actúan por su fuerza perlocutoria sobre la pareja-receptora, para «atraerla» (hechizos «para atraer al futuro esposo»). También, a través de la capacidad per- 
locutoria específica, subordinada a la causalidad y a los principios mágicos, las estrategias poéticas reforzadas por las poiéticas implican la relación de comunicación con fuerzas mediadoras sagradas destinadas a receptar y actuar en el sentido de mantener el fenómeno mágico, para su realización.

La manera de generar las variantes poéticas motiva la presencia de unas microestructuras con una función evidente en el establecimiento del contacto entre las instancias comunicativas, entre el ejecutor y el receptor presente en distintas hipóstasis: dicho de otra manera, algunos componentes discursivos se evidencian por una evidente función fática (R. Jakobson), introduciendo acentos retóricos de ejecución del texto con su finalidad específica.

La consideración de los textos mágicos por su valor poético intrínseco, sobre la base del respeto a unas normas impuestas por el código y por la actualización de unos modelos tradicionales, permite la percepción de la dimensión estética del discurso mágico. La relación entre los dos términos, magia y poesía, es biunívoca. Lo mágico penetra - como ya se ha observado- «en el halo de lo inefable y de la emoción estética», por «el poder que palabras como hechizo y hechizar tienen en la poesía, donde el valor intrínseco de las palabras, la fuerza emocional que liberan, son las que más sobreviven y las que más claramente están reveladas» (Malinowski, 1996: 109). Por el contrario, el estado poético se infiltra inconscientemente en las configuraciones mágicas, matizando el abanico de los estados emotivos, añadiendo a las vivencias de naturaleza psíquica, emociones con implicaciones estéticas. Reteniendo las dominantes psico-social y utilitaria del fenómeno mágico, no podemos eludir el lado de la organización coherente del texto como texto, con una lógica interior relevante para la función poética (R. Jakobson), al igual que no podemos pasar por alto un cierto estado emocional estético, a veces no-concienciado, otras veces, al contrario, explícito en enunciados del tipo: «este hechizo es más bonito/es muy bonito».

La función referencial del discurso mágico plantea el problema de la articulación del texto como signo con una determinada realidad. Relacionado con la perspectiva pragmática sobre el texto, el universo poético construido por el texto se refiere a tres niveles actanciales relacionados: a/ la referencia sagrada, ejemplar, en la expresión invocatoria del hechizo que apela a fuerzas míticas y religiosas, para aumentar las posibilidades; b/ la referencia relacionada con la función del ejecutor (D); c/ la referencia individual concerniente a la persona (P) 
con una función triple: solicitante, receptor y beneficiario, y en algunas variantes, con papel de ejecutor; d/ el referente individual representando al compañero deseado hacia el cual se dirige la fuerza mágica de la palabra pronunciada, destinada a sensibilizarle y dominarle; e/ la referencia colectiva, del grupo.

La funcionalidad del texto mágico-erótico y la intencionalidad de su producción, en interacción con el componente de la praxis, determina, en realidad, la supresión de la referencia primaria correspondiente al estado no deseado de la persona (P): frustración, rechazo e incertidumbre en las relaciones con el compañero «futuro» y con el ámbito comunitario. La generación del texto poético-mágico oralmente, y su organización interna específica, significan precisamente la abolición de la referencia de primer rango (de esta realidad no deseada) y la liberación de una referencia de rango secundario que fundamenta el mundo construido en la visión imaginativa del texto. El mundo del texto proyecta el universo deseado, una nueva realidad, opuesta a la primera, en la que se afirma la idea de belleza y prioridad, de realización erótica marital, de conseguimiento del prestigio en las relaciones intracomunitarias. El discurso no insiste en lo que es, sino en lo que los interlocutores piensan y proyectan para que sea como realidad.

Las investigaciones semióticas distinguen entre el discurso factual y el discurso de ficción, señalando las diferencias específicas, pero también las similitudes. En el discurso factual que designa referentes reales, el acto de referencia a objetos reales, los elementos lingüísticos, tienen una función denotativa (descripciones definidas, nombres propios, demostrativos, deícticos, etc.) (Ducrot y Schaeffer, 1996: 242). Se ha observado, en general, que el discurso ficticio tiene denotación literal nula. Pero algunos teóricos han ampliado la noción de referencia, incluyendo en ella la denotación metafórica y las modalidades de referencia no denotativa. Consideran las características literarias intrínsecas y los valores expresivos como pertenecientes a la estructura referencial de los sistemas simbólicos, al igual que la denotación. La falta de denotación de una obra, su carácter ficticio, no le impiden tener una dimensión referencial. Más allá de las diferencias que confieren la marca de especificidad, el discurso de ficción se acerca al de tipo factual, por la ilusión de una narración de tipo factual (Cf. Ducrot y Schaeffer, 1996: 246). De algunos estudios (Pavel, 1988) se pueden retener opiniones muy matizadas sobre los mundos ficticios. El autor mencionado parte de la idea de que en la existencia cotidiana ya vivimos en una pluralidad de mundos, pasando sin cesar de un mundo a otro. Puesto que nos 
desplazamos entre diferentes mundos ficticios y construimos relaciones más o menos estrechas entre estos mundos y los que habita el hombre histórica y socialmente, la ficción no puede ser definida en oposición a la realidad. Debe situarse sobre todo en una escala continua de mundos más o menos «reales», más o menos «ficticios», cuyas intersecciones definen la realidad humana.

Los hechizos son entidades casi autónomas, realidades problemáticas y abiertas que responden a unas preguntas y crean la esperanza de unas resoluciones. El estudio del texto mágico persigue el universo construido, un montón de mundos posibles, nacidos como alternativa al mundo real en el imperio del deseo y de la expectación. Los mundos de los discursos mágicos son y deben ser verosímiles: el texto mágico reúne temas, argumentos y técnicas de persuasión. La forma de organización del texto y la distribución de los constituyentes en modelos específicos tienen relevancia para el arte de la composición determinada funcionalmente. Las estrategias y los procedimientos con función persuasiva relacionan la retórica de la emisión con la retórica de la recepción, apuntando a los dos polos de la comunicación, el practicante que se esfuerza por captar la atención y el interés del receptor, y el receptor que recibe la información, a la espera del efecto deseado.

A modo de ejemplo, seleccionamos del conjunto de estrategias retóricas mágicas algunos componentes verbales imperativos relacionados con microestructuras enumerativas y analógicas.

4.1. La retórica del imperativo (el modo del deseo y de la orden) tiene aplicación predilecta en la invocación de las fuerzas astrales determinantes: estrellas, luna, sol, y de los elementos mediadores, agua y fuego, transfigurados míticamente. Estos discursos invocatorios son especialmente relevantes para el sincretismo arcaico magia-mito, perpetrado, reconstruido y siempre adecuado por la tradición, en su recorrido evolutivo. Las formas de imperativo afirmativo, asociadas a las formas nominales de vocativo, transponen, en su contenido semántico, la intención de embellecer a la persona solicitante y de sensibilización erótica del compañero deseado. La llamada mágica del poder del agua purificadora y regeneradora tiene una finalidad precisa que el texto explicita necesariamente, fuera de cualquier ambigüedad o incoherencia: «Lávame,/hazme bella,/para gustarles a los jóvenes» (Gorovei, 1931: 313).

Las fórmulas invocatorias son se construyen frecuentemente en estructuras contrastivas de paralelismo, en las que las formas verbales 
de imperativo negativo, en relación con las formas nominales vocativas de dirigirse hacia los apoyos sagrados-míticos, imponen la negación de unas acciones, para acentuar por las formas imperativas afirmativas las acciones correspondientes, orientadas firmemente hacia la transformación proyectada. Por ejemplo, la invocación del amanecer, representación arcaica de origen mítico, implica la negación de una acción que define el fenómeno en su manifestación concreta («no te levantes») para la afirmación e intensificación, por contraste, de la acción equivalente, transferida mágicamente, en vista del embellecimiento de la persona («levántate»):

Voi zori,

Nouă surori,

Voi nu vă sculați

Pe garduri uscate,

Pe șanțuri vărgate, vs.

$C i$ vă sculaț $i$

Pe statul meu,

Pe vorba mea,

Pe cuvîntul meu. (Pamfile 1998: 43)

(vosotras albas

nueve hermanas

vosotras no os levantéis

vs.

sobre verjas secas

sobre hoyos con sombra

Si no, levantaos

sobre mi estar

sobre mi palabra (Pamfile, 1998: 43).

El efecto del cambio de la cualidad física y espiritual de la persona y de su posición, en el contexto de la vida comunitaria de tipo tradicional-rural, transpone a menudo el acto volitivo-desiderativo en objetivaciones verbales de subjuntivo con valor imperativo. Los segmentos discursivos se configuran con vivas sostenidas por la lógica mágica, para la integración del individuo en la colectividad y para la reglamentación de la evolución existencial de éste, en el contexto de las relaciones intercomunitarias: «Que sea conocido,/que sea nombrado,/que sea cariñoso,/que sea fuerte».

La repetición del verbo copulativo, con relieve funcional-retórico, asocia la serie enumerativa de las características atribuidas a la persona que va a beneficiarse — en el contexto de la mentalidad tradicional- 
del efecto del fenómeno mágico. En el interior de la serie enumerativa, las características deseadas señalan el aspecto físico («fuerte») de la persona (aquí, de sexo masculino), el aspecto comportamental erótico («cariñoso») y la reglamentación de la posición del individuo en el ámbito social, en el conjunto de las relaciones interpersonales («conocido, nombrado»). En el marco de la misma versión, las significaciones de la secuencia discursiva enumerativa están reforzadas por la relación con otro segmento textual, relacionado funcional y semánticamente, estructurado simétricamente, en un paralelismo triádico:

$\begin{array}{ccc} & \text { a } & \begin{array}{l}\text { Un i-o fi cuvîntul, } \\ \text { I }\end{array} \\ & \text { b } & \text { Să-i fie ca untul: } \\ \text { II } & \text { a } & \begin{array}{l}\text { Un i-o fi statul, } \\ \text { b }\end{array} \\ & & \text { Să-i fie ca-mpăratul: } \\ & \text { a } & \text { Un i-o fi graiul, } \\ \text { III } & \text { b } & \text { Să-i fie ca raiul. }\end{array}$

(I a Donde esté su palabra,

b que sea como la mantequilla:

II a Donde esté él mismo,

b que esté como un emperador:

III a donde esté su habla,

b que sea como el paraíso).

Cada término del paralelismo presenta dos componentes, $a$ y $b$, que ponen de manifiesto la relación analógico-mágica entre los contenidos expresados:

a) Los registros sometidos a la transformación mágica, física («el estar») y espiritual («la palabra», «el habla»), representan el elemento primordial, que se compara.

b) El polo segundo, con el que se compara, revela el nivel de la ejemplaridad existencial, física y moral. 
Las estrategias discursivas, mágicas de «atraer al futuro esposo» por la invocación de los ayudantes astrales míticos —los mismos que los de los hechizos «de embellecimiento y prioridad» en el ámbito comunitario- o de otras fuerzas sobrenaturales seleccionadas del sistema mitológico rumano, como la serpiente, ponen de manifiesto una constante subjuntivo-imperativa con referencia a dos acciones esenciales para la retórica funcional de los textos: «Que te vayas/que vayas a por mi predestinado» $\rightarrow$ «ique me lo traigas!/ique me lo envíes!» Los acentos retóricos subjuntivo-imperativos son evidentes en las series enumerativas que detallan las intervenciones persuasivas sobre el predestinado, atribuidas a una fuerza mítico-mediadora: «Con las lenguas/lo empujes,/El corazón/Le atravieses». Las acciones expresadas por los verbos con valor imperativo se hallan en relación con una forma de invocación de la serpiente mítica, resultado de la metamorfosis del cinturón mágico (el objeto ritual utilizado en la praxis mágic), en la ficción del texto mágico: «Cintura, mi cinturón,/Hazte serpiente laurel,/serpiente dragón,/con escamas de oro,/completamente de oro!» (Teodorescu, 1985: 377).

Algunas versiones explican el papel de la ayuda invocada en las configuraciones textuales ficticias, en formas verbales imperativas afirmativas, que revelan la transformación de la actitud del compañero, por el poder de la magia: «Hazlo,/Transfórmalo,/A este joven», con la intención final de realizar el matrimonio: «Que venga,/Que se case conmigo» (Gorovei, 1931: 315).

En las situaciones de autoejecución del hechizo en el contexto de las prácticas mágicas, la comunicación directa, imperativa, pone en relación a la persona que pronuncia el texto con el compañero que debe ser activado mágicamente: «Fulano, no te detengas,/Levántate, no duermas,/iVen enseguida,/Que te voy a querer!» (Teodorescu, 1985: 54).

Por una inspirada combinación de los procedimientos retóricos, la progresión numérica acentúa la expresividad funcional-mágica del imperativo. La repetición verbal: «tráeme... traedme» («a mi amor»), en relación con la serie nominal vocativa, por la que la invocación del ayudante astral se refuerza con cada término, por aumento numérico: «una estrella - dos estrellas - tres estrellas - cuatro estrellas - cinco estrellas - seis estrellas - siete estrellas - ocho estrellas - nueve estrellas», interactúan semánticamente con un segmento textual retomado con cada unidad añadida: «tres veces, hasta el alba, en este jarrón con flores» (Floarea-Marian, 1893: 97). 
Por su contenido y en relación con las demás formas de expresión, métodos y técnicas retóricas, en un contexto discursivo-mágico, el imperativo confiere energía y vigor al poder.

4.2. La función de los textos poéticos imperativos «de embellecimiento y atracción del amado» se refuerza por el efecto de las series enumerativas que la imaginación creativa anónima propone, con la esperanza de reformar al ser en formas superlativas: «Yo bella / Yo hermosa, / Yo, de todo el mundo, / Elegida». En la lógica del discurso mágico, la superlativización estética provoca una percepción general de excepción, marcada también por la calidad persuasiva de la enumeración, que relaciona los acentos nominales: «Todo el mundo, / Todo el pueblo», con los verbales que nombran las acciones esperadas: «A mí me miraba, / A mí me deseaba, / Y ante todos me daba».

Las microestructuras enumerativas detallan, necesariamente, las fuentes donde «brotan el amor, la belleza y todos los nombres», por la retórica mágica del imperativo. En algunos hechizos, la constante enumerativa pone en evidencia la ejemplaridad de unas parejas plurales, ficticias, que se imponen como modelos en la construcción del prestigio y de la prioridad de la persona, en su ámbito comunitario. El amor es traído: «de emperadores y emperatrices, / de príncipes y príncesas, / sacerdotes y sacerdotizas, / de novios y novias» (FloareaMarian, 1893: 100).

En los textos de invocación del astro diurno, la solarización del ser por medio de la fuerza cósmica mítica es explicitada en dos microestructuras enumerativas relacionadas, la primera con la acentuación de las formas verbales: «Con tres cálzame, / Con tres rodéame, / Tres en la mejilla escríbeme», y la segunda con el reforzar de las formas nominales, poniendo de manifiesto los elementos que concentran la calidad esperada: «Tres en las pestañas, / tres en las cejas, / Tres en las coletas / ¡Ponédmelas!».

Más allá de la diversidad de las formas de expresión, se impone como invariante la idea de reconocimiento cualitativo de la persona en el grupo. Las formas adjetivales tienen un valor referencial, pero en un sentido proyectivo, calificando la imagen deseada, como efecto de la ejecución mágica. En vistas a la transformación de la actitud del grupo hacia la persona que vive el sentimiento de frustración en las relaciones interpersonales o que actúa para prevenir, los textos diversifican y particularizan la imagen del ámbito comunitario, poniendo acentos en cada componente interno del grupo. Se crea así también la 
posibilidad de que cada elemento enumerado asocie el término repetido «todos» («todos los pequeños, / todos los jóvenes, / todos los del pueblo») (Pamfile, 1998: 43), que fija la idea de integridad. La suma de las partes enumeradas, las formas plurales, la repetición del adjetivo pronominal son procedimientos retóricos, que responden al principio funcional mágico de la totalidad.

En los hechizos de atracción del predestinado, en la estrategia de la comunicación directa, imperativa, las microestructuras enumerativas ponen de manifiesto las formas verbales que indican las acciones de activación agresiva del compañero, que debe ser dominado y dirigido, por métodos mágicos, hacia la persona que le espera: «Golpéalo, / En la tierra, / derrúmbalo, / Y hacia mí, / ¡encamínalo!» (Gorovei, 1931: 314).

La progresión realizada en la micro serie enumerativa verbal: «golpéalo, / derrúmbalo, / encamínalo» es la expresión de la dinámica mágica por la que se persigue la constitución de la pareja, doblemente motivada: personalmente, por el deseo de la muchacha que solicita el hechizo, y sobreindividual, por la ley del destino, por el cumplimiento del destino. El texto impone una forma de presión sobre el compañero, perturbando su orden y armonía de la existencia cotidiana, por la negación imperativa de unas necesidades enumeradas $y$, por lo tanto, subrayadas: «iQue no le dejes, / estar, / beber, / comer, / y tampoco le des descanso!» Estas son restricciones mágicas, aplicadas al predestinado, para determinarle a adherir al acto matrimonial: «Hasta María va a ir, / Y con María, / ¡se va a casar!».

Tomando del hechizo terapéutico el procedimiento retórico-mágico de unas series enumerativas que contienen componentes del cuerpo, algunas versiones en el destino detallan las partes del cuerpo, sobre las cuales se ejerce la acción mágica de transformación: «Donde te vaya a clavar, / que te claves, / En los pies, / en las manos, / en el hígado, / en los riñones, / en las cejas, / en las pestañas, / en los ojos, / En las orejas de $\mathrm{N} »$. Si en el hechizo en contra de la enfermedad la enumeración era una forma de configurar la entidad, por la aplicación del principio mágico de la totalidad y en consenso con la óptica popular de cura de la parte por referencia a la totalidad, en vistas al restablecimiento integral del enfermo, en los textos mágicos «de atracción del predestinado» la serie enumerativa compone el total, por la selección de unas partes, en relación con la proyección de unas acciones imperativas de dominación del compañero: «Para que no pueda estar, / Para que no pueda beber». 
La búsqueda insistente del predestinado cobra acentos especiales en series enumerativas en las que la repetición del verbo ser con valor de predicado y del elemento de relación condicional de (si) se relaciona con variables del numeral ordinal, con el efecto de una progresión de la idea y del estado expresados por el texto: «Cintura, mi cinturón, / Ve con mi predestinado, / Si está aquí en el pueblo, / si está en el segundo, / si está en el tercero, / si está en el cuarto, / si está en el quinto, / si está en el sexto, / si está en el séptimo, / si está en el octavo, / si está en el noveno, / esté donde esté» (Teodorescu, 1985: 377). La retórica del texto y la técnica argumentativa están subordinadas — con cada versión - a la finalidad matrimonial que se necesita explicitar: «Hasta que no me vea / en su casa, / en su patio, / en su entrada». Aunque orientado hacia el compañero predestinado, el efecto mágico no se limita sólo a acapararlo y sensibilizarlo, sino que se extiende, significativamente, a todo el conjunto de relaciones y de papeles implicados en el acto del matrimonio, al que el texto alude.

4.3. Las construcciones discursivas mágicas apelan frecuentemente a microestructuras analógicas que aumentan el grado de expresividad y la relevancia funcional, en el sentido de la transformación deseada de la imagen y del comportamiento de una persona (P) en relación con la imagen colectiva y de acuerdo con el comportamiento del grupo al que pertenece:

«Cum se alege soarele

Dintre toti norii,

Așa să fiu și eu aleasă

De toti boierii

Si i de toate cucoanele:

De toți flăcăii

Și de toate domnișoarele.»

«Como se elige el sol,

entre todas las nubes,

De igual forma me elijan a mí

todos los ricos

y todas las damas,

todos los jóvenes

$\mathrm{y}$ todas las doncellas».
I-primer término de la analogía

II-segundo término de la analogía

II-segundo término de la analogía 
El primer término de la comparación es especialmente expresivo por la selección de las cualidades de claridad, brillo, belleza y pureza, por la imagen de la separación «del sol», de «todas las nubes». Repitiendo la forma verbal («elige...que me elijan»), como una concretización en el discurso de la demanda de similitud mágica, el segundo término de la analogía refuerza las connotaciones positivas atribuidas a la persona evidenciada por el procedimiento de la singularización, en contraste con una totalidad fuertemente marcada por las formas pronominales retomadas: «todos»-«todas».

No es casual la creación de la imagen del conjunto, en agrupaciones binarias que sugieren, o bien a la pareja pre-marital («los jóvenes»«las señoritas»), o bien a la pareja marital, con el relevo de una posición social especial ( «los ricos»-«las damas»). Variantes como ésta acentúan retóricamente tanto el aspecto general de la reestructuración valórica del yo en relación con el grupo, como el aspecto particular de la normalización de la existencia en el período anterior al acto del matrimonio y en vistas a la realización de éste.

Las microestructuras comparativas insisten en el modelo solar, superlativo de belleza y brillo, percibido como referente de máxima eficacia en el proceso de transfiguración mágica, benéfica de la persona. La relación analógica asocia la transferencia de la cualidad:

«iQue brille

como tú, Sol! -primer término de la analogía

-segundo término de la analogía

la percepción ejemplar de la persona dentro del grupo:

«Tal y como te mira

a tí, el pueblo,

Por igual me miren

Ellos a mí,

desde la cabeza

hasta los pies» (Floarea-Marian, 1893: 111).
I - el primer término de la analogía

II - segundo término de la analogía

Las estructuras cultural-mágicas con finalidad erótica pre-marital permanecen todavía en el universo rural rumano, con mutaciones internas específicas a la evolución del fenómeno, determinadas por la multitud de factores contextuales históricos. Permanecen y van a permanecer mientras la lógica mágica, los principios que la gobiernan motiven el 
soporte de mentalidad individual y comunitaria. Permanecen y van a permanecer incluso en las condiciones de un contexto social marcado por un pragmatismo en plena función, mientras los portadores de estos modelos culturales encuentren en ellos la esperanza de ajustar la oportunidad o de realización de ésta cuando tarda en presentarse.

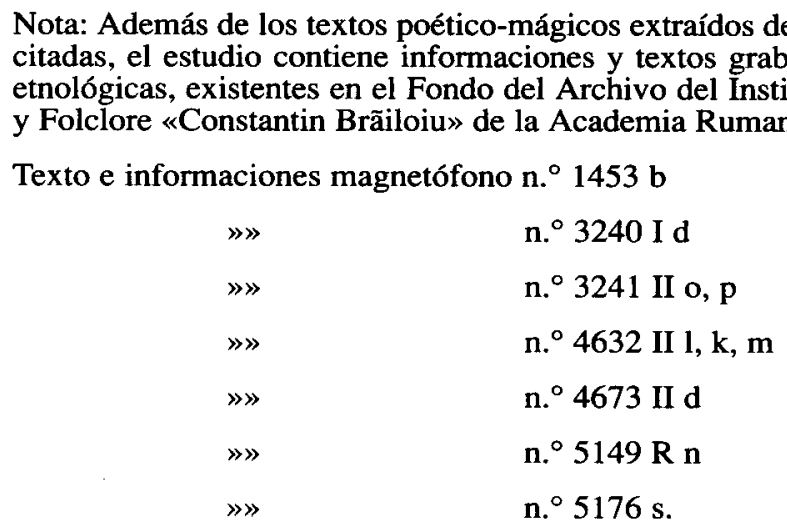

\section{Referencias bibliográficas}

BACHELARD, G. (1997). Apa și visele. Eseu despre imaginația materiei. Bucuresti: Univers.

BERNEA, E. (1997). Spațiu, timp și cauzalitate la poporul român. București: Humanitas.

CASSIRER, E. (1994). Eseu despre om. O introducere in filozofia culturii umane. Bucures ti: Humanitas.

Chevalier, J. y GhEerBrandT, A. (1994). Dicționar de simboluri, II. București: Artemis.

CoATU, N. (1998). Structuri magice traditionale. Bucures, ti: ALL.

CREȚU, V. (1998). Existența ca întemeiere. Timis, oara: Facla.

DUCROT, O. y SCHAEFFER, J. (1996). Noul dicționar enciclopedic al științelor limbajului. Bucuresti: Babel.

DuRAND, G. (1968). L'imagination symbolique. Paris: Payot.

EvseEv, I. (1994). Dicționar de simboluri și arhetipuri culturale. Timis, oara: Amarcord.

FlOREA-MARIAN, S. (1883). Vrăji, farmece și desfaceri. București Extras din Analele Academiei Române. Memoriile Sect, iunii Literare. Seria II. Tomul XV.

- (1994). Sărbătorile la români, I. Bucures,ti: Editura Fundat,iei Culturale Române. 
GoRoveı, A. (1931). Descîntecele românilor. București: Regia M.O. Imprimeria Natională.

MALINOWSKI, B. (1996). Magie, stiință și religie. Bucuresti: ALL.

MAMULAS I. y BIANU, C. (s.a.). Dicționar de parapsihologie. București: Corvin \& RAI.

PAMFILE, T. (1998). Dragostea în datina tineretului român. București: Saeculum.

Pavel, T. (1988). Univers de la fiction. Paris: Gallimard.

Pavelescu, G. (1944). Mana în folclorul romînesc. Contributii pentru cunoasterea magicului. Sibiu: Tiparul Tip. Crafft \& Drotleff.

Teodorescu, G. Dem. (1985). Poezii populare române, II. București: Minerva.

VAN GENNEP, A. (1996). Riturile de trecere. Iași: Polirom.

VIANU, T. (1973). Arta prozatorilor romîni. Bucuresti: Editura pentru literatură. 